\title{
ДІАГНОСТИЧНА ЦІННІСТЬ ЛАБОРАТОРНИХ ПОКАЗНИКІВ У ПІДТВЕРДЖЕННІ НЕСТРЕПТОКОКОВОЇ ЕТІОЛОГІЇ ГОСТРИХ ТОНЗИЛОФАРИНГІТІВ У ДІТЕЙ
}

ВДНЗ України «Буковинський державний медичний університет», м. Чернівці

\begin{abstract}
Резюме. 3 метою оптимізації лікування гострих тонзилофарингітів у дітей вивчено діагностичне значення окремих клініко-параклінічних тестів у верифікації нестрептококової етіології захворювання. Першу клінічну групу склали 66 дітей із нестрептококовою етіологією захворювання. До другої (II) клінічної групи увійшло 33 дитини 3 гострим стрептококовим тонзилофарингітом. Встановлено, що у дітей із гострим нестрептококовим тонзилофарингітом реєструвався вірогідно вищий рівень еритроцитів та гемоглобіну в сироватці крові порівняно з пацієнтами II клінічної групи. У
\end{abstract}

Вступ. Гострий тонзилофарингіт (ГТФ) належить до найбільш поширених позалікарняних інфекційних захворювань у світі. Біль у горлі, як головний симптом ГТФ, є найбільш частою причиною звернення за амбулаторною медичною допомогою або самолікування [8].

Переважна більшість випадків ГТФ має вірусне походження (респіраторні віруси, ентеровіруси, віруси Епштейна-Барр) і тому не потребують будь-якої етіотропної терапії. Серед бактеріальних збудників найбільш важливе значення має $\beta$ гемолітичний стрептокок групи А (БГСА), з яким пов'язано від 5 до 15\% випадків ГТФ серед дорослих та 20-30\% - у дітей [1,3]. Деякі автори вказують на можливу роль інших бактеріальних збудників, таких збудників, як стрептококи груп С та G, Streptococcus pneumoniae [4], Arcanobacterium haemolyticum, анаероби, Mycoplasma pneumoniae i Chlamydia pneumoniae [9]. Проте відсутність чітких доказів щодо участі цих мікроорганізмів у формуванні ускладнень ГТФ, а також можливість носійства подібної флори змушують дослідників критично ставитися до необхідності проведення антибіотикотерапії відносно цих збудників. Таким чином, сучасна стратегія антибактеріальної терапії ГТФ повинна грунтуватися на етіологічній розшифровці діагнозу. Практично єдиним показом до застосування протимікробної терапії є стрептококова (БГСА) етіологія захворювання (за винятком дифтерії, гонококового тонзиліту і т.д.).

Незважаючи на наявність достатньої кількості рекомендацій та алгоритмів, антибактеріальну терапію продовжує необгрунтовано отримувати переважна більшість пацієнтів із синдромом ГТФ $[2,6]$, що може призводити до зростання резистентності патогенних мікроорганізмів, ризику виникнення небажаних реакцій на антибіотики, а також підвищення вартості лікування.

Як свідчать дані літератури, ні клінічна картина (включаючи наявність нашарувань на мигдаликах та лихоманку), ні навіть рівень «класичних» (С) Л.А. Іванова, І.Б. Горбатюк, 2016
80,7 \% пацієнтів із гострим нестрептококовим тонзилофарингітом відмічалося зниження вмісту інтерлейкіну8 у сироватці крові (менше 15,0 пг/мл), а в групі порівняння - у $61,2 \%$ випадків $(\mathrm{P} \varphi<0,05)$. Встановлено, що при реєстрації в сироватці крові хворих на тонзилофарингіт вмісту ІЛ-8 менше 15,0 пг/мЛ відносний ризик нестрептококової етіології захворювання склав - 1,7 (95 \%ДІ 1,4-2,0), абсолютний ризик - 0,2, при співвідношенні шансів 2,7 (95 \%ДІ 1,3-5,0).

Ключові слова: діти, гострий тонзилофарингіт, етіологія.

маркерів запалення (лейкоцитоз, нейтрофільоз, «зсув» вліво, рівні С-реактивного білка і прокальцитоніну) не мають достатньої чутливості та специфічності для диференціальної діагностики вірусних і бактеріальних тонзилітів [5].

На теперішній час підтвердження БГСАетіології захворювання за допомогою бактеріологічного дослідження та/або експрес-тестування матеріалу з піднебінних мигдаликів і задньої стінки глотки вважаються «золотим стандартом» діагностики гострого бактеріального тонзилофарингіту [8]. Проте остаточний результат бактеріологічного засіву на живильне середовище лікар отримує не раніше 3-5-ї доби, а експрес-тести на виявлення БГСА в сучасних умовах недоступні для рутинного використання в амбулаторній практиці та при надходженні до стаціонару, що змушує його призначати етіотропну терапію, орієнтуючись лише на клінічну картину та загальноклінічні аналізи.

Таким чином, пошук додаткових клінічнопараклінічних критеріів, які б дали змогу вирізнити стрептококову та нестрептококову етіологію ГТФ у дітей, слід вважати актуальним.

Мета дослідження. Для оптимізації лікування гострих тонзилофарингітів у дітей вивчити діагностичне значення окремих клінікопараклінічних тестів у верифікації нестрептококової етіології захворювання.

Матеріал і методи. Для досягнення мети роботи на базі відділення повітряно-краплинних інфекцій ОДКЛ м. Чернівці обстежено 99 дітей, що перебували на стаціонарному лікуванні з приводу гострих тонзилофарингітів. Першу (I, основну) групу склали 66 пацієнтів із гострим тонзилофарингітом нестрептококової етіології, що підтверджено негативним результатом бактеріологічного дослідження змиву з мигдаликів та задньої стінки глотки. До другої (II) клінічної групи увійшли 33 дитини з гострим стрептококовим тонзилофарингітом. Про стрептококову етіологію за- 
хворювання свідчив позитивний результат культурального дослідження матеріалу із зіва.

Середній вік пацієнтів основної групи склав $(9,2 \pm 0,6)$ років, групи порівняння $(7,3 \pm 0,8)$ років ( $>0,05)$. Частка хлопчиків серед пацієнтів I клінічної групи становила 51,5,3 $\pm 6,1 \%$, у групі порівняння $-37,5 \pm 8,5 \%(\mathrm{p}>0,05)$. За основними клінічними характеристиками групи були зіставлюваними.

Крім загальноклінічного обстеження, всім пацієнтам проведено визначення вмісту в сироватці крові інтерлейкіну-6 (ІЛ-6) та ІЛ-8. Вміст інтерлейкінів у сироватці крові визначали методом імуноферментного аналізу з використанням стандартних наборів реагентів. Робота виконана згідно $з$ вимогами до рандомізованого порівняльного дослідження в паралельних групах за методом “дослід-контроль”.

Отримані результати дослідження аналізували за допомогою методів біостатистики та клінічної епідеміології. При нормальному розподілі використовували параметричні методи аналізу, 3 оцінкою відмінностей за Стьюдентом (критерій t). Обробку даних проводили 3 використанням пакета прикладних програм «STATISTICA 7,0». Для встановлення діагностичної цінності визначали їх чутливість (ЧТ), специфічність (СП), передбачувану позитивну (ППЦ) та негативну цінність (НПЦ). 3 позиції клінічної епідеміології оцінювали атрибутивний та відносний ризики, а також співвідношення шансів 3 обчисленням їх довірчих інтервалів (95 \% ДІ).

Результати дослідження та їх обговорення. При оцінці результатів загального аналізу крові у пацієнтів груп спостереження вдалося встановити вірогідну різницю лише за кількістю еритроцитів та рівнем гемоглобіну в крові (табл.1). Зниження вмісту еритроцитів та рівня гемоглобіну в крові хворих на стрептококовий тонзилофарингіт можна пояснити більш виразним інтоксикаційним синдромом із тенденцією до розвитку анемії.

Слід зазначити, що інших вірогідних відмінностей, зокрема за такими показниками, як кількість лейкоцитів, зсув лейкоцитарної формули, ШОЕ, у пацієнтів груп порівняння не виявлено.
Водночас виявлена чітка тенденція до відсутності лейкоцитозу в периферичній крові пацієнтів із нестрептококовою етілогією ГТФ. Так, середній вміст лейкоцитів у крові менше $8,9 \times 10^{9} /$ л реєструвався у 57,6 \% пацієнтів I групи та в 48,8 \% представників другої $(\mathrm{p}<0,05)$. Чутливість цього лабораторного тесту у виявленні нестрептококового тонзилофарингіту становила 57,6 \%, специфічність - 55,6 \%, передбачувана цінність позитивного результату - $54,1 \%$, негативного $59,1 \%$. Водночас встановлено, що відносний ризик нестрептококової етіології ГТФ при реєстрації у хворого менше $8,9 \times 10^{9} /$ л лейкоцитів периферичної крові склав 1,7 (95 \%ДІ 0,9-2,9), абсолютний ризик - 0,1 при співвідношенні шансів - 1,4 (95 \%ДІ 0,6-3,3).

Порівняльний аналіз вмісту інтерлейкіну-6 та інтерлейкіну-8 у сироватці крові дітей із ГТФ різної етіології наведено в таблиці 2.

Таким чином, у дітей першої клінічної групи виявлено вірогідно нижчий рівень інтерлейкіну-8 у сироватці крові, який продукується під впливом бактерійних ендотоксинів. Згідно 3 даними літератури, підвищений рівень ІЛ-8 у сироватці крові асоціює з гострими запальними станами і корелює 3 тканинною інфільтрацією нейтрофілів, яка супроводжує бактеріальний запальний процес [7]. Встановлено, що у 80,7 \% хворих на ГТФ нестрептококової етіології відзначалося зниження вмісту інтерлейкіну-8 у сироватці крові (менше 15,0 пг/мл), тоді як у другій групі воно траплялося лише у 61,2 \% випадків $(\mathrm{P} \varphi<0,05)$.

Таким чином, нижча концентрація цього прозапального цитокіну в дітей першої клінічної групи, ймовірно, вказує на небактеріальний етіологічний чинник гострого тонзилофарингіту.

Порівняльний аналіз вмісту інтерлейкіну-6 у сироватці крові дітей із ГТФ різної етіології показав, що рівень даного цитокіну, що синтезує білки гострої фази запального процесу в організмі, суттєво не відрізнявся, однак, відмічено чітку тенденцію до його зниження у дітей із нестрептококовим ГТФ. Слід звернути увагу, що в більшості пацієнтів першої клінічної групи $(63,1 \%)$ реєструвався нормальний вміст ІЛ-6 (вікова норма

Таблиця 1

Окремі показники загального аналізу крові у дітей груп порівняння

\begin{tabular}{|c|c|c|c|}
\hline Ознака & $\begin{array}{c}\text { I група } \\
(\mathrm{n}=66)\end{array}$ & $\begin{array}{c}\text { II група } \\
(\mathrm{n}=33)\end{array}$ & $\mathrm{P}$ \\
\hline Середній вміст еритроцитів $\left(10^{12} /\right.$ л) & $4,2 \pm 0,1$ & $3,9 \pm 0,1$ & $<0,05$ \\
\hline Рівень гемоглобіну (г/л) & $129,7 \pm 1,8$ & $121,8 \pm 2,6$ & $<0,05$ \\
\hline
\end{tabular}

Таблиця 2

Аналіз вмісту ІЛ-6 та ІЛ-8 у сироватці крові дітей груп порівняння

\begin{tabular}{|c|c|c|c|}
\hline Ознака & $\begin{array}{c}\text { I група } \\
\text { (n=66) }\end{array}$ & $\begin{array}{c}\text { II група } \\
(\mathrm{n}=32)\end{array}$ & $\mathrm{P}$ \\
\hline Середній вміст ІЛ-6 у сироватці крові (пг/мл) & $13,2 \pm 2,2$ & $15,1 \pm 2,6$ & $>0,05$ \\
\hline Середній вміст ІЛ-8 у сироватці крові (пг/мл) & $18,6 \pm 3,8$ & $44,2 \pm 11,4$ & $<0,05$ \\
\hline
\end{tabular}


10,0 пг/мл) у сироватці крові, тоді як у другій групі - лише у 48,3 \% випадків (Р $\varphi>0,05)$.

Відзначено, що при реєстрації в сироватці крові хворих на тонзилофарингіт вмісту ІЛ-6 у межах вікової норми відносний ризик нестрептококової етіології захворювання становить 1,4 (95 \%ДІ 1,0-1,7) при співвідношенні шансів 1,9 (95 \%ДІ 0,8-4,3).

Показники діагностичної цінності даного лабораторного тесту щодо виявлення нестрептококового ГТФ відносно гострого тонзилофарингіту стрептококового генезу виявилися такими: ЧТ - 80,7 \%, СП - 38,8 \%, ППЦ - 56,8 \%, НПЦ $66,7 \%$.

Водночас встановлено, що нестрептококова етіологія гострого тонзилофарингіту в дітей асоціювала зі зниженням концентрації інтерлейкіну8 у сироватці крові (менше 15,0 пг/мл) відносно групи дітей із ГТФ, зумовленого БГСА: відносний ризик - 1,7 (95 \%ДІ 1,4-2,0), абсолютний ризик - 0,2, при співвідношенні шансів - 2,7 (95\% ДІ 1,3-5,0).

Таким чином, пацієнти з нестрептококовими тонзилітами характеризувалися відсутністю анемічного синдрому, вмістом лейкоцитів периферичної крові менше $8,9 \times 10^{9} /$ л, нормальним рівнем інтерлейкіну-6 та зниженням інтерлейкіну-8.

Враховуючи неоднорідність показників діагностичної цінності, наведені вище параклінічні тести можуть бути використані лише комплексно 3 іншими клінічно-параклінічними критеріями діагностики гострого нестрептококового тонзилофарингіту .

\section{Висновки}

1. У хворих на гострий нестрептококовий тонзилофарингіт реєструвався вірогідно вищий рівень еритроцитів та гемоглобіну в сироватці крові порівняно 3 пацієнтами із стрептококовою етіологією захворювання.

2. У 80,7 \% хворих на гострий нестрептококовий тонзилофарингіт відзначалося зниження вмісту інтерлейкіну-8 у сироватці крові (менше
15,0 пг/мл), порівняно з пацієнтами, у яких захворювання викликане $\beta$-гемолітичним стрептококом групи $\mathrm{A}-61,2 \%$ випадків $(\mathrm{P} \varphi<0,05)$.

3. При реєстрації в сироватці крові хворих на тонзилофарингіт вмісту ІЛ-8 менше 15,0 пг/мл відносний ризик нестрептококової етіології захворювання склав - 1,7 (95 \%ДІ 1,4-2,0), абсолютний ризик - 0,2, при співвідношенні шансів 2,7 (95 \%ДІ 1,3-5,0).

\section{Література}

1. Дарманян А.С. Проблема острого тонзиллита в детском возрасте / А.С. Дарманян, М.Д. Бакрадзе // Мед. совет. - 2013. - № 1. - С. 69-72.

2. До питання етіологічної діагностики тонзилофарингітів у дітей / О.К. Колоскова, Л.А. Іванова, О.В. Бєлашова [та ін.] // Актуал. інфектол. - 2014. - № 2 (3). C. $78-82$.

3. Поляков Д.П. Принципы антибактериальной терапии стрептококкового тонзиллофарингита / Д.П. Поляков // Вопр. соврем. педиатрии. - 2014. - № 13 (2). C. 83-88.

4. Acute tonsillopharyngitis associated with atypical bacterial infection in children: natural history and impact of macrolide therapy / S. Esposito, S. Bosis, E. Begliatti [et al.] // Clin Infect Dis. - 2006. - Vol. 43 (2). - P. 206-209.

5. Bista M. Tonsillar microbial flora: a comparison of infected and non-infected tonsils / M. Bista, R.C. Amatya, P.Basnet // Kathmandu Univ Med J. - 2006. - Vol. 4 (1). - P. $18-21$

6. Boccazzi A. Streptococcal tonsillopharyngitis: clinical vs. microbiological diagnosis / A. Boccazzi, M.Garotta, S. Pontari // Infez Med. - 2011. - Vol. 19 (2). - P. 100-105.

7. Clinical Practice Guideline for the Diagnosis and Management of Group A Streptococcal Pharyngitis: 2012 Update by the Infectious Diseases Society of America / S.T. Shulman, A.L. Bisno, H. Clegg [et al.] // Clinical Infectious Diseases. - 2012. - Vol. 55 (10). - P. 1279-1282

8. Structural and Immunological Characteristics of Chronically Inflamed Adenotonsillar Tissue in Childhood D. Passali, V. Damiani, G.C. Passali [et al.] // Clinical and Vaccine Immunology. - 2004. - Vol. 11 (6). P. 1154-1157.

9. The antibiotic prescribing behaviourof physicians for acute tonsillopharyngitis in primary care / H. Canli, E. Saatci, N. Bozdemir [et al.] // Ethiop Med J. - 2006. Vol. 44 (2). - P. 139-143

\section{ДИАГНОСТИЧЕСКАЯ ЦЕННОСТЬ ЛАБОРАТОРНЫХ ПОКАЗАТЕЛЕЙ В ПОДТВЕРЖДЕНИИ НЕСТРЕПТОКОККОВОЙ ЭТИОЛОГИИ ОСТРОГО ТОНЗИЛЛОФАРИНГИТА У ДЕТЕЙ}

\section{Л.А. Иванова, И.Б. Горбатюк}

Резюме. С целью оптимизации лечения острых тонзиллофарингитов у детей изучено диагностическое значение отдельных клинико-параклинических тестов для верификации нестрептококковой этиологии заболевания. Первую клиническую группу составили 66 детей с нестрептококковой этиологией заболевания. Ко второй (II) клинической группе вошло 33 ребенка с острым стрептококковым тонзиллофарингитом. Установлено, что у больных с острым нестрептококковым тонзиллофарингитом регистрировался достоверно выше уровень эритроцитов и гемоглобина в сыворотке крови по сравнению с пациентами II клинической группы. В 80,7 \% больных с острым нестрептококковым тонзиллофарингитом отмечалось снижение содержания интерлейкина-8 в сыворотке крови (менее 15,0 пг / мл), а в группе сравнения - в 61,2 \% случаев $(\mathrm{P} \varphi<0,05)$. Установлено, что при регистрации в сыворотке крови больных тонзиллофарингитом ИЛ-8 меньше 15,0 пг / мл относительный риск нестрептококковой этиологии заболевания составил - 1,7 (95 \% ДИ 1,4-2,0), абсолютный риск - 0, 2, при соотношении шансов 2,7 (95 \% ДИ 1,3-5,0)

Ключевые слова: дети, острый тонзиллофарингит, этиология. 


\section{DIAGNOSTIC VALUE OF LABORATORY FINDINGS TO CONFIRM A STREPTOCOCCAL ETIOLOGY OF ACUTE TONSILLOPHARYNGITIS IN CHILDREN}

\section{L.A. Ivanova, I.B. Horbatiuk}

Abstract. In order to optimize the treatment of acute tonsillopharyngitis in children the diagnostic value of certain clinical-paraclinical tests in the verification of nonstreptococcal etiology of the disease has been studied. The first clinical group included 66 children with nonstreptococcal etiology of the disease. The second (II) clinical group included 33 children with acute streptococcal tonsillopharyngitis. The patients with acute nonstreptococcal tonsillopharyngitis were found to possess significantly higher levels of red blood cells and hemoglobin in the blood serum as compared with the patients of II clinical group. In $80,7 \%$ of patients with acute nonstreptococcal tonsillopharyngitis the reduction of interleukin- 8 in the blood serum (less than $15,0 \mathrm{pg} / \mathrm{ml}$ ) was detected, and in the comparison group - in $61,2 \%$ of cases $(\mathrm{R} \varphi<0,05)$. The registration of IL-8 less than $15,0 \mathrm{pg} / \mathrm{ml}$ in the blood serum of patients with tonsillopharyngitis was found to have a relative risk of nonstreptococcal etiology - 1,7 (95\% CI 1,4-2,0), absolute risk - 0 2, the odds ratio of 2,7 (95\% CI 1,3-5,0).

Key words: children, acute tonsillopharyngitis, etiology.

Higher State Educational Institution of Ukraine "Bukovinian State Medical University” (Chernivtsi)

Рецензент - проф. С.А. Левицька

Buk. Med. Herald. - 2016. - Vol. 20, № 3 (79). - P. $72-75$

Надійшла до редакції 15.04.2016 року

(ㄷ Л.А. Іванова, І.Б. Горбатюк , 2016 